Media Farmasi p.issn 0216-2083 e.issn 2622-0962 Vol. XV No. 1, April 2019,

\title{
EKSTRAK ETANOL DAUN MENIRAN (Phyllanthus niruri L.) TERHADAP MENCIT JANTAN (Mus musculus) YANG DIINDUKSI ASAM ASETAT SEBAGAI ANALGETIK
}

\author{
Meniran leaf ethanol extract (phyllanthus niruri l.) On heart (Mus musculus) detected asset acid \\ as analgetic
}

\section{Rugayyah Alyidrus $^{1 *}$, Dini Ayu Ariastiwi ${ }^{2}$, Yunita Mardi ${ }^{3}$}

Universitas Mega Rezky Makassar

${ }^{*}$ Koresponden: Rugayyah Alyidrus, Email : rugayyahalyidrus@ymail.com,HP :081342107588

DOI: https://doi.org/10.32382/mf.v15i1.813

\begin{abstract}
Meniran leaves (Phyllanthus niruri L.) contain flavonoids which are useful as analgesics whose mechanism of action inhibits the action of the cycloxyagenase enzyme. This research was to know the testing of analgesic activity of ethanol extract of meniran leaves (Phyllanthus niruri L.) against male mice (Mus musculus) after being induced by $1 \%$ acetic acid. In this research used chemical stimulation method (stretching) Results data were analyzed statistically by measuring using the ANOVA (Analysys of Varience) method. Fifteen mice were divided into 5 groups. Each mice was induced using $1 \%$ acetic acid. Negative control ( $\mathrm{Na} \mathrm{CMC}$ ), positive control (Ibuprofen $400 \mathrm{mg}$ ), meniran dosage extract $0,1 \mathrm{~g} / 20 \mathrm{gBB}$, dosage $0,2 \mathrm{~g} / 20 \mathrm{gBB}$ and dosage $0,4 \mathrm{~g} / 20 \mathrm{gBB}$. Stretching measurements were carried out every time interval of 5 minutes to 60 minutes after induction of acetic acid. The result of research showed that the use of dosage $100 \mathrm{mg}, 200 \mathrm{mg}$ and $400 \mathrm{mg} / \mathrm{gBB}$ in mice can show analgesic activity in mice (Mus musculus).
\end{abstract}

Keywords : Analgesic, meniran leaves (Phyllanthus niruri L.), stretching

\begin{abstract}
ABSTRAK
Daun meniran (Phyllanthus niruri L.) memiliki fungsi sebagai analgetik dimana terdapat senyawa flavonoid yang mekanisme kerjanya menghambat kerja enzim siklooksigenase. Tujuan Penelitian ini adalah untuk mengetahui ekstrak daun meniran (Phyllanthus niruri L.) dapat memberikan aktivitas efek analgetikterhadap mencit jantan (Mus musculus)yang telah diinduksi asam asetat $1 \%$. Dalam penelitian ini menggunakan metode rangsangan kimia (geliat) dan data hasil dianalisis pengukuran geliat secara statistik menggunakan metode ANOVA (Analisys Of Variance). Penelitian ini menggunakan lima belas ekor mencit jantan dibagi menjadi 5 kelompok. Setiap mencit diinduksi menggunakan asam asetat $1 \%$. Kontrol negatif (Na CMC), kontrol positif (Ibuprofen $400 \mathrm{mg}$ ), ekstrak daun meniran dosis $0,1 \mathrm{~g} / 20 \mathrm{gBB}$ mencit, dosis $0,2 \mathrm{~g} / 20 \mathrm{gBB}$ mencit, dan dosis $0,4 \mathrm{~g} / 20 \mathrm{gBB}$ mencit. Pengukuran geliat dilakukan setiap interval waktu 5 menit sampai 60 menit setelah penginduksian asam asetat $1 \%$. Hasil penelitian menunjukkan bahwa ekstrak daun meniran (Phyllanthus niruri L.) dapat memberikan efek analgetik pada penggunaan dosis $100 \mathrm{mg}, 200 \mathrm{mg}$, dan $400 \mathrm{mg} / \mathrm{gBB}$.
\end{abstract}

Kata kunci: analgetik, daun meniran (Phyllanthus niruri L.), geliat

\section{PENDAHULUAN}

Tanaman berkhasiat obat telah digunakan masyarakat indonesia sejak dahulu dan diwariskan secara turun-temurun.Khasiat tanaman obat di kalangan masyarakat dapat berupa pengalaman, tradisi dan jenis tanaman yang ada disetiap daerah masing-masing (Jansen dan Awaloei, 2015). Salah satu jenis

tanaman yang digunakan sebagai obat tradisional adalah daun meniran (Phyllanthus niruri L.) merupakan tanaman dari famili Euphorbiaceae yang tumbuh liar disekitar kita.Bagian dari herba meniran (daun, akar dan batang) memiliki banyak manfaat sebagai obat tradisional, karena mengandung beberapa 
senyawa kimia yaitu alkaloid (sekurinin), flavonoid (kuersetin, kuersitrin, isokuersitrin, astragalin, nirunin, niruside, rutin, leukodelfinidin dan galakotekin), dan lignan (filantin dan hipofilantin). Pada tanaman meniran (Phyllanthus niruri L.), senyawa flavonoid dapat berfungsi sebagai analgetik (Mangunwardoyo, 2009).

Flavonoid merupakan senyawa yang mampu melindungi membran lipid dari kerusakan dan menghambat enzim siklooksigenase I yang dimana jalur pertama sintesis mediator nyeri seperti prostaglandin. Daun meniran yang mengandung flavonoid memiliki aktivitas sebagai analgetik. Rasa sakit atau nyeri merupakan pertanda ada bagian tubuh yang bermasalah, yang merupakan suatu gejala, yang

\section{METODE}

\section{Desain, Tempat dan Waktu}

Desain penelitian yang dilakukan adalah MetodeEksperimental Laboratorim dengan melakukan pengujian pada mencit jantan (Mus musculus), berdasarkan metode rangsangan kimia (metode geliat) yang dilakukan bertujuan untuk melihat aktivitas analgetik daun meniran (Phyllanthus niruri L.) pada mencit jantan (Mus musculus).

Penelitian ini dilakukan di Laboratorium Farmakologi Universitas Mega Rezky Makassar pada bulan September 2018.

\section{Alat}

Alat yang digunakan antara lain: cawan porselin (Iwaki Pirex $\left.{ }^{\circledR}\right)$, eksikator (Normax), gelas kimia (Iwaki Pirex ${ }^{\circledR}$ ), gelas ukur (Iwaki Pirex ${ }^{\circledR}$ ), kandang hewan, kanula (New Blunt Cannula), kertas saring, labu ukur (Iwaki Pirex $\left.{ }^{\circledR}\right)$, lumpang (RRC), mangkok maserasi, pipet tetes (Pudak), rotavapor (Scilogex), stopwatch, timbangan analitik (Ohaus $\left.^{\circledR}\right)$ dan wadah maserasi (toples).

\section{Bahan}

Bahan yang digunakan yaitu: Aluminium Foil $\left(\right.$ Klinpak $\left.^{\circledR}\right)$, Asam Asetat $1 \%$, Daun Meniran (Phyllanthus niruri L), Etanol 70\%, Ibuprofen 400mg (Kimia Farma), Mencit Jantan (Mus musculus), Na CMC 0,5\%.

\section{Langkah-langkah Penelitian}

Sampel yang digunakan diperoleh dari Dusun Batulotong Kec. Larompong Kab. Luwu, Sulawesi Selatan. Pengambilan sampel dilakukan dipagi hari pada pukul 07.00 dengan fungsinya adalah melindungi serta memberikan tanda bahaya tentang adanya gangguangangguan di dalam tubuh seperti peradangan (rematik, encok), infeksi kuman atau kejang otot. Rasa nyeri dapat terjadi disebabkan oleh rangsangan baik mekanis maupun kimiawi yang ditimbulkan oleh kerusakan pada jaringan dan melepaskan zat-zat tertentu yang disebut mediator (perantara) nyeri seperti bradikinin, histamin, serotonin, dan prostaglandin (Afriantiet al., 2014).

Berdasarkan hal ini, maka dilakukan penelitian apakah ekstrak etanol daun meniran (Phyllanthus niruri L.) dapat memberikan efek analgetik pada mencit jantan yang telah diinduksi asam asetat.

cara daun dipisahkan dari tangkai, buah batang dan akarnya.Hewan coba yang digunakan yaitu mencit jantan (Mus musculus) yang sehat yang memiliki BB 20-30g, berprilaku normal, berbulu halus, dimana setiap harinya terjadi penyusutan BB. Dalam penelitian ini digunakan 15 ekor mencit dan setiap perlakuan ada 3 ekor mencit.

Pada pembuatan ekstrak dilakukan metode maserasi dengan menggunakan etanol $70 \%$. Tahapan pembuatannya adalah Sebanyak 500g daun meniran (Phyllanthus niruri L.) yang sudah dikeringkan dimasukkan ke dalam wadah maserasi yang ditambahkan etanol $70 \%$ sebanyak 2000ml, didiamkan selama 5 hari. Ekstrak cair etanol $70 \%$ yang diperoleh kemudian dimasukkan kedalam mangkok maserasi lalu diuapkan dengan menggunakan rotavapor. Setelah diperoleh ekstrak etanol kental maka dimasukkan kedalam cawan poreselin dan kemudian di tutup dengan menggunakan aluminium foil agar tidak terkontaminasi oleh mikroorganisme setelah itu ekstrak disimpan dalam eksikator.

Ditimbang sebanyak $500 \mathrm{mg}$ serbuk Serbuk Na CMC dan dilarutkan dalam aquadet hangat sambil diaduk-aduk sesekali $d$ tambahkan aquadest sampai larut. Setelah larut semua, maka ditambahkan sisa aquadest sampai didapatkan volume larutan Na CMC 100ml.

Ibuprofen sangat sukar larut dalam air. Untuk itu, ibuprofen diberikan dalam bentuk suspensi $\mathrm{Na}$ CMC 0,5\% sedikit demi sedikit sambil dikocok dan diadkan sampai $100 \mathrm{ml}$.

Diambil asam asetat sebanyak $1 \mathrm{ml}$, kemudian diencerkan dengan aquadest dalam labu ukur hingga volume $100 \mathrm{ml}$. 
Ekstrak etanol daun meniran (Phyllanthus niruri L.) yang telah ditimbang sesuai dengan dosis yakni 100mg, 200mg dan 400mg digerus dan ditambahkan larutan NaCMC 0,5\% kemudian dicampurkan dengan aquadest sampai $100 \mathrm{ml}$.

Pengujian analgetik yang dilakukan dengan membagi 5 kelompok hewan uji dimana masing-masing kelompok terdiri dari 3 ekor mencit dari 15 mencit yang telah disiapkan. Mencit tersebut dipuasakan selama 18 jam tetapi tetap diberikan air minum. Kemudian diberikan perlakuan pada masing-masing kelompok mencit.

a) Kelompok I

Kelompok mencit diberikan suspensi ekstrak dosis $100 \mathrm{mg} / \mathrm{kg}$ BB lalu diberi asam asetat $1 \%$ secara intraperitonial.

b) Kelompok 2

Kelompok mencit diberikan suspensi ekstrak dosis $200 \mathrm{mg} / \mathrm{kg}$ BB lalu diberi asam asetat $1 \%$ secara intraperitonial.

c) Kelompok 3

Kelompok mencit diberikan suspensi ekstrak dosis $400 \mathrm{mg} / \mathrm{kg}$ BB lalu diberi asam asetat $1 \%$ secara intraperitonial.

d) Kelompok 4

Kelompok mencit diberikan suspensi Ibuprofen $400 \mathrm{mg} / \mathrm{kg} \mathrm{BB}$ (kontrol positif) lalu diberi asam asetat $1 \%$ secara intraperitonial.

e) Kelompok 5

Kelompok mencit diberikan suspensi $\mathrm{Na}$ CMC $0,5 \%$ (kontrol negatif) lalu diberi asam asetat $1 \%$ secara intraperitonial.

Setelah dilakukan pemberian, diukur selama 1 jam tiap 5 menit dengan cara yang sama.

Perhitungan besar kecilnya daya analgetik pada masing-masing kelompok dapat ditentukan setelah didapat jumlah kumulatif geliat mencit selama 1 jam dengan menghitung presentase daya analgetiknya masing kelompok dengan rumus:

$$
\begin{aligned}
& \% \mathrm{DA}=100-\left(\frac{P}{K} \times 100 \%\right) \\
& \text { DA = Daya Analgetik (\%) } \\
& \mathrm{P} \quad=\text { Jumlah Kumulatif Kelompok } \\
& \text { Perlakuan } \\
& \mathrm{K}=\text { Jumlah Kumulatif Kelompok } \\
& \text { Kontrol Negatif }
\end{aligned}
$$

\section{HASIL}

Pada penelitian ini maka diperoleh hasil bahwa ekstrak etanol daun meniran (Phyllanthus niruri L) dapat memberikan efek analgetik pada mencit jantan (Mus musculus) yang telah diinduksi asam asetat.

\section{PEMBAHASAN}

Dalam penelitian ini hewan uji yang digunakan yaitu mencit, dimana mencit dapat memberikan efek geliat dan iritasi pada perut apabila diinduksi bahan kimia secara intraperitonial (Parmar dan Prakash, 2006). Mencit juga memiliki gen yang mirip dengan manusia, termasuk hewan mamalia, kemampuan berkembangbiak tinggi sehingga cocok untuk digunakan sebagai hewan uji. Selain itu penanganan untuk mencit termasuk mudah, karena bentuknya yang kecil menyebabkan obat yang digunakan relatif cepat berefek. Mencit jantan digunakan karena memiliki kondisi biologis yang lebih stabil dibandingkan dengan mencit betina yang dipengaruhi siklus estrus. Selain keseragaman jenis kelamin, juga digunakan keseragaman berat badan (20-30 g) dan umur (lima minggu) yang bertujuan untuk memperkecil variabilitas biologis antara hewan uji yang digunakan, sehingga dapat memberikan respon yang relatif lebih seragam terhadap rangsangan kimia yang digunakan pada penelitian ini (Wahyuningsih dan Linda, 2015)

Sebelum perlakuan, mencit terlebih dahulu diadaptasikan selama 1 minggu dan dipuasakan selama 18 jam tetapi masih diberi air minum, agar mencit dapat beradaptasi dengan lingkungannya. Kemudian, pemberian sediaan secara oral dilakukan 30 menit sebelum diberi penginduksi.

Tujuan penenlitian ini untuk mengetahui ekstrak daun meniran meniran (Phyllanthus niruri L.) dapat memberikan efek analgetik dengan dosisdosis $100 \mathrm{mg}, 200 \mathrm{mg}$ dan $400 \mathrm{mg}$ setelah diinduksi asam asetat. Metode pengujian analgetik yang digunakan yaitu metode rangsang kimia atau metode geliat, yang diinduksi asam asetat 1\%.Asam asetat digunakan sebagai perangsang nyeri karena asam asetat dapat menimbulkan nyeri pada jaringan sehingga dapat menimbulkan geliat pada mencit sebagai tanda nyeri yaitu menarik kedua kakinya ke belakang dan perut menyentuh lantai.Kontrol positif digunakan ibuprofen 400mg. Ibuprofen adalah obat yang bersifat analgetik

dengan daya anti inflamasi yang tidak terlalu kuat. Absorbsi ibuprofen cepat melalui lambung dan kadar maksimum dan plasma dicapai setelah 1-2 jam. Kontrol negatif yang digunakan 
ialah Na CMC 0,5\% karena tidak memiliki efek analgetik dan tidak bersifat toksik.

Pengujian analgetik dilakukan dengan cara mengelompokkan hewan uji menjadi 5 kelompok dengan masing-masing 1 kelompok terdapat 3 ekor hewan uji. Kelompok kontrol negatif diberi Na CMC 0,5\% dan kontrol positif diberi pembanding Ibuprofen secara per oral. Kemudian pada kelompok dosis 100, 200, dan $400 \mathrm{mg} / \mathrm{kgBB}$ diberi ekstrak etanol daun meniran secara per oral. Pengamatan dilakukan berdasarkan jumlah geliat yang merupakan reaksi nyeri yang diperlihatkan oleh hewan uji, pengamatan dilakukan selama 1 jam dengan selang waktu pengamatan setiap 5 menit setelah pemberian asam asetat $1 \%$ secara intraperitonial.

Data yang diperoleh ditunjukkan dengan uji statistik untuk menguji sebaran datanya dengan menggunakan uji Homogenity of Variance didapatkan nilai signifikasi sebesar 0,18 selanjutnya dengan nilai signifikasi yang lebih kecil dari 0,05 (0,00> 0,05) maka terpenuhi syarat untuk uji ANOVA One-way dan data menyebar secara normal atau homogen. Persentase daya analgetik yang didapat kontrol positif: $76,82 \%$, dosis I: $73,56 \%$, dosis II: $82,61 \%$, dan dosis III: 96,02\%. Kemampuan daun meniran dalam mengatasi rasa nyeri karena adanya kandungan flavonoid yang merupakan senyawa yang dapat melindungi membran lipid dari kerusakan dan menghambat enzim siklooksigenase I yang merupakan jalur pertama sintesis mediator nyeri seperti prostaglandin (Afrianti et al, 2014). Dalam pengujian ini kenaikan konsentrasi ekstrak berbanding lurus dengan daya analgetik. Semakin besar konsentrasi ekstrak maka semakin besar daya analgetik yang diperoleh. Harapannya dapat dikembangkan formulasi ekstrak daun meniran sebagai obat herbal analgetik

\section{KESIMPULAN}

Berdasarkan hasil penelitian menunjukkan bahwa ekstrak etanol daun meniran (Phyllanthus niruri L.) dapatmemberikan efek analgetik pada mencit jantan (Mus musculus) yang diinduksi asam asetat.

\section{SARAN}

Diharapkan dilakukan penelitian selanjutnya dengan menggunakan metode yang berbeda.

\section{UCAPAN TERIMA KASIH}

Teman-teman di Laboratorium Farmakologi dan Fitokimia Universitas Mega Rezky Makassar yang telah banyak membantu.

\section{DAFTAR PUSTAKA}

Afrianti, Ria, Revi Yenti, dan Dewi Meustika. 2014. Uji Aktifitas Analgetik Ekstrak Etanol Daun Pepaya (Carica papaya L.) Pada Mencit Putih jantan yang di Induksi Asam Asetat 1\%. StiFa Indonesia Yayasan Perintis Padang: Padang.

Hadi, Pratiwi. 2007. Efek Ekstrak Etanol Meniran (Phyllanthus niruri L.) Sebagai Analgetik Pada Mencit Betina Galur Swiss Webster. UKM: Bandung.

Harmita, dan Radji, M. 2008. Buku Ajar Analisis Hayati, Edisi 3. Buku Kedokteran EGC: Jakarta.

Hasanah, Rusni, dan Mashuri. 2015. Analisis Pertumbuhan Mencit (Mus musculus) ICR Dari Hasil Perkawinan Dengan Pemberian Pakan AD1 dan AD2. UIN Alauddin: Makassar

Jansen, Wuisan, dan Awaloei. 2015. Uji Efek Antipiretik Ekstrak Menitan (Phyllanthus niruri L.) Pada Tikus Wistar (Rattus novergicus) Jantan Yang Diinduksi Vaksin DPT-HB. FKUSRM : Manado

Katzung, G. B. 1998. Farmakologi Dasar dan Klinik Edisi VI. EGC: Jakarta.

Mangunwardoyo, Wibowo. 2009. Ekstraksi dan Identifikasi Senyawa Antimikroba Herba Meniran (Phyllanthus niruri L.). UI: Jakarta.

Parmar, N.S., dan S. Prakash. 2006. Screening methods in pharmacology. Apha Science International. Oxford.

Supriyadi, H. dan Dein, I. 2009. Kegunaan Ekstrak daun Meniran (Phyllanthus niruri) Bagi Pengendalian Penyakit Ikan Akibat Infeksi Bakteri Aeromonas Hydrophila. Sekolah Tinggi Perikanan: Jakarta Selatan.

Wahyuningsih, S.S., dan Linda W. 2015. Uji Efek Analgetik Infusa Daun Beluntas (Pluchea indica L.) Pada Mencit Jantan Galur SSwiss. Poltekkes Bhakti Mulia Sukoharjo: Jawa Tengah. 
Tabel 1. Hasil Rendamen Ekstrak Etanol Daun Menitran (Phyllanthus niruri L.)

\begin{tabular}{lccc}
\hline Jenis Pelarut & $\begin{array}{c}\text { Berat Sampel } \\
\text { Kering }(\mathbf{g})\end{array}$ & $\begin{array}{c}\text { Berat Ekstrak } \\
\text { Kental }(\mathbf{g})\end{array}$ & $\begin{array}{c}\text { Rendamen } \\
(\boldsymbol{\%})\end{array}$ \\
\hline Etanol 70\% & 500 & 216 & 65,2 \\
\hline
\end{tabular}

Tabel 2. Persentasi daya analgetik kelompok perlakuan ekstrak etanol daun meniran (Phyllanthus niruri L.) dosis $100 \mathrm{mg} / \mathrm{kgBB}, 200 \mathrm{mg} / \mathrm{kgBB}$, dan $400 \mathrm{mg} / \mathrm{kgBB}$ dan kontrol positif (Ibuprofen 400 $\underline{\mathrm{mg})}$

\section{Jumlah kumulatif geliat}

\begin{tabular}{ccccc}
\cline { 3 - 5 } Hewan uji & & \multicolumn{3}{c}{ Ekstrak etanol daun meniran } \\
\cline { 3 - 5 } & Ibuprofen & Dosis 100mg & Dosis 200mg & Dosis 400mg \\
\hline Mencit I & 19 & 16 & 17 & 4 \\
\hline Mencit II & 18 & 27 & 5 & 7 \\
\hline Mencit III & 27 & 30 & 26 & $96,02 \%$ \\
\hline \% DA & $76,82 \%$ & $73,56 \%$ & $82,61 \%$ & \\
\hline
\end{tabular}

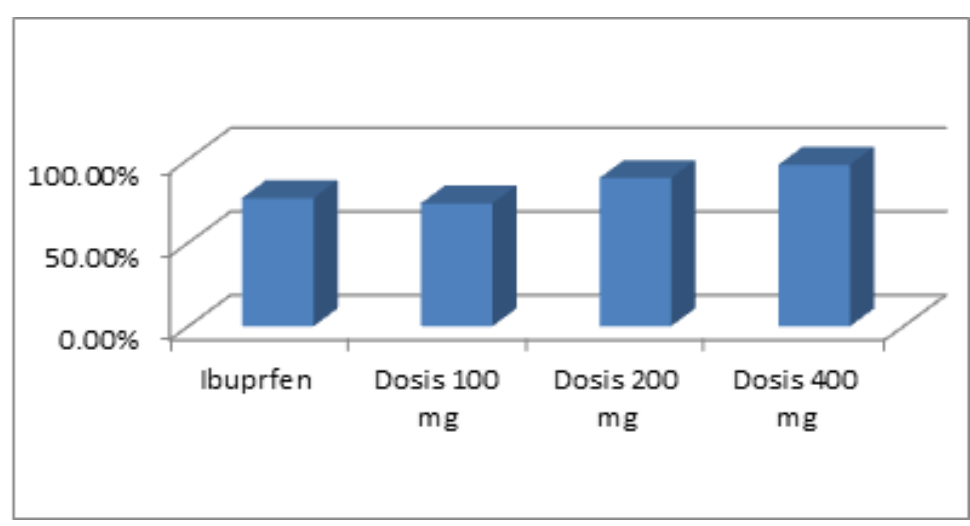

Gambar I. Grafik Persentase Daya Analgetik Pada Mencit (Mus musculus) 